\title{
Seasonal and Lactational Changes in Mineral Composition of Milk from Iberian Red Deer (Cervus elaphus hispanicus)
}

\author{
L. Gallego, ${ }^{*}$ T. Landete-Castillejos, ${ }^{*}+\ddagger^{1}$ A. Garcia, ${ }^{*} † \ddagger$ and P. J. Sánchez§ \\ *Departamento de Ciencia y Tecnología Agroforestal, ETSIA, Universidad de Castilla-La Mancha, \\ 02071 Albacete, Spain \\ †Instituto de Investigación en Recursos Cinegéticos, IREC (CSIC, UCLM, JCCM), Campus Universitario s/n, \\ 02071 Albacete, Spain \\ ‡Grupo de Recursos Cinegéticos, Instituto de Desarrollo Regional, Universidad de Castilla-La Mancha, \\ 02071 Albacete, Spain \\ §CERSYRA, Av. Vino s/n, 13300 Valdepeñas, Ciudad Real, Spain
}

\section{ABSTRACT}

Milk minerals are important for calf growth, and they have other roles as well, such as immune regulation. This 2-yr study examined content of $\mathrm{Ca}, \mathrm{P}, \mathrm{Mg}, \mathrm{Na}, \mathrm{K}$, $\mathrm{Fe}$, and $\mathrm{Zn}$ in milk of 54 Iberian red deer hinds through 18 wk of lactation. Mean mineral composition of fresh milk was ash $=1.168 \pm 0.007 \%, \mathrm{Ca}=2,330 \pm 20 \mathrm{mg} /$ $\mathrm{kg}, \mathrm{P}=640 \pm 10 \mathrm{mg} / \mathrm{kg}, \mathrm{K}=1,100 \pm 10 \mathrm{mg} / \mathrm{kg}, \mathrm{Na}=$ $385 \pm 3 \mathrm{mg} / \mathrm{kg}, \mathrm{Mg}=138 \pm 1 \mathrm{mg} / \mathrm{kg}, \mathrm{Zn}=12.5 \pm 0.2$ $\mathrm{mg} / \mathrm{kg}$, and $\mathrm{Fe}=0.65 \pm 0.03 \mathrm{mg} / \mathrm{kg}$. All minerals except $\mathrm{Mg}$ varied by week of lactation, but variation was usually $<10 \%$ except for $\mathrm{Fe}(83 \%$ variation) and $\mathrm{Zn}(30 \%$ variation); both of those minerals increased as lactation proceeded. Increased concentrations of $\mathrm{Fe}$ and $\mathrm{Zn}$ in later lactation compensated for the reduction in milk production in mid and late lactation such that daily production was less variable for $\mathrm{Fe}$ (55\% variation) or $\mathrm{Zn}$ (79\% variation) than for other minerals (118 to 135\% variation). Potassium content of milk decreased across time, but that effect occurred primarily during the last few weeks of lactation. Calving later vs. early in the calving season had variable effects on concentrations of different minerals: $\mathrm{P}, \mathrm{Mg}$, and $\mathrm{K}$ concentrations were not affected; $\mathrm{Ca}, \mathrm{Mg}$, and $\mathrm{Na}$ were all lower in milk from later calving hinds; and both $\mathrm{Fe}$ and $\mathrm{Zn}$ had higher concentrations in milk from hinds that calved later in the season. Lactating hinds seem to maintain a more stable daily yield of the microminerals $\mathrm{Fe}$ and $\mathrm{Zn}$ in milk compared with more variable concentrations of macrominerals as lactation progresses. Because of the essential role of $\mathrm{Fe}$ and $\mathrm{Zn}$ in immune function, a more stable supply of those minerals might be important to the health of growing red deer calves.

Key words: red deer, milk mineral composition, birth date, lactation

Received June 21, 2005.

Accepted September 30, 2005

${ }^{1}$ Corresponding author: Tomas.Landete@uclm.es

\section{INTRODUCTION}

Iberian red deer, as well as other subspecies of deer, are seasonal breeders (García et al., 2002); a high percentage of births are noted in the first month (mid May to mid June), and lower percentages of births occur throughout the remainder of the calving season, which ends in late September. Late calving noticeably affects lactation; thus, hinds calving late naturally produce less, but more concentrated, milk. Milking hinds substitute protein (most directly related to growth; LandeteCastillejos et al., 2001, 2003b) with fat in their milk, and they lose more weight than hinds calving early (Landete-Castillejos et al., 2000b). Production yields of milk nutrients are also lower in late-calving hinds; thus, their calves do not grow as large as early born calves (Landete-Castillejos et al., 2001). Similar results have been found in artificially induced calving date delays (Landete-Castillejos et al., 2004, 2005), and in both cases, early born calves had higher milk intake compared with calves nursing late-calving hinds (LandeteCastillejos et al., 2000a, 2005).

In contrast to protein and fat, less is known about factors that affect mineral content of milk, although effects of stage of lactation, milk accumulation, feed, and genetic variance have been reported (Peaker, 1977; Vegarud et al., 2000). A particularly important factor is milk lactose content, as balanced osmolality between body fluids and milk results in opposing contents of lactose (osmotically active) and sodium and potassium (Peaker, 1977). Minerals in milk occur as inorganic ions and salts but also form complexes with proteins and peptides, carbohydrates, fats, and small molecules (Vegarud et al., 2000). Of these, the most known and important association is that of casein and $\mathrm{Ca}$ in all species studied (Flynn and Cashman, 1997; Holt, 1997; Vegarud et al., 2000; Silva et al., 2001). Thus, it is likely that factors affecting protein content of milk, such as calving date, also affect concentration of at least some milk minerals. This may affect calf growth, because 
Table 1. Main nutrients and minerals of pasture and a meal mixture of barley, alfalfa, oats, and sugar beets offered to Iberian red deer hinds. The deer also had access to barley straw.

\begin{tabular}{lcc}
\hline Nutrient & Pasture & Meal \\
\hline CP, \% & 18 & 11 \\
Fiber, \% & 21 & 9 \\
Fat, \% & 3.1 & 2.2 \\
P, ppm & 0.91 & 0.90 \\
Ca, \% & 2.26 & 2.08 \\
K, \% & 3.75 & 0.80 \\
Mg, \% & 0.46 & 0.09 \\
Na, ppm & 345 & 402 \\
Zn, ppm & 31 & 27 \\
Fe, ppm & 320 & 160 \\
\hline
\end{tabular}

minerals are important for juvenile growth in many mammals. In fact, they can be so limiting that, for example, just the supplementation of $\mathrm{Zn}$ or $\mathrm{Cu}$ may increase growth of young pigs (Paik, 2001).

The current study examined milk mineral composition of macrominerals $\mathrm{Ca}, \mathrm{P}, \mathrm{Mg}, \mathrm{Na}$, and $\mathrm{K}$ as well as the 2 most essential microminerals, Fe and Zn. Effects of week of lactation and calving date as well as confounding factors, such as differences in protein, fat, or lactose (osmotically active) percentage and betweenyear variations, were also examined.

\section{MATERIALS AND METHODS}

\section{Animals and Sampling Regimen}

Subjects included 54 Iberian red deer hinds and their calves kept in a $10,000-\mathrm{m}^{2}$ open door enclosure on an irrigated pasture including tall fescue, Festuca arundinacea (52.4\%); orchardgrass or cocksfoot, Dactylis glomerata (28.6\%); lucerne, Medicago sativa (14.3\%); and white clover, Trifolium repens (4.8\%). The hinds ranged in age from 2 to $9 \mathrm{yr}$, and the study involved $2 \mathrm{yr}$ of data. In 2001, 13 hinds calved within a standard season (May 16 to July 8) with $<60 \mathrm{~d}$ between birth of the first and last calves. In 2002, 41 hinds were included within a calving season from May 23 to September 8. Of those 41,10 calved in the standard calving period (within 50 $\mathrm{d}$ after the first calf birth), and 31 calved later (>80-d delay after the first calf birth). No calves were born between 43 to $86 \mathrm{~d}$ after the first birth. Therefore, the 2 groups calving in 2002 had distinctly differing early and late calving periods, and data from all 41 hinds calving in 2002 were used, although group sizes were not equal.

Both during gestation and throughout lactation, hinds were fed ad libitum; diets were based on suggestions by Brelurut et al. (1990) using pasture, barley straw, and a meal mixture ( $11 \% \mathrm{CP})$ from barley, alfalfa, oat, and sugar beets (Table 1). Calves had access to feed destined to hinds, although they were not observed to feed on them during the experiment. No record of individual intake of feed was attempted.

Milking was conducted on wk 2, 4, 6, 10, 14, and 18 of lactation. Hinds were isolated from calves for $6 \mathrm{~h}$, and no preisolation milking was allowed for ethical reasons explained in Landete-Castillejos et al. (2000a). Individuals were milked under anesthesia (xylazine at $0.5 \mathrm{mg} /$ $\mathrm{kg}$ of body mass; ketamine at $1 \mathrm{mg} / \mathrm{kg}$; reverted with yohimbine at $0.25 \mathrm{mg} / \mathrm{kg}$ of body mass) using a machine milking set up to 50:50 massage:milking ratio and 44 $\mathrm{kPa}$ of vacuum. Once anesthesia was induced, $10 \mathrm{IU}$ of oxytocin was injected in the right jugular vein $1 \mathrm{~min}$ before milking began to induce milk let-down. Milk production and composition were assessed as explained in Landete-Castillejos et al. (2000b, 2001). At each milking, 10-mL milk samples were collected for use in mineral analyses.

\section{Mineral Analyses}

To prepare for mineral analyses, $10-\mathrm{mL}$ milk samples were dried for $3 \mathrm{~h}$ at $102^{\circ} \mathrm{C}$ and then for $24 \mathrm{~h}$ at $130^{\circ} \mathrm{C}$. After this period, samples were incinerated at $520^{\circ} \mathrm{C}$ for $12 \mathrm{~h}$. Ashes were then dissolved with $10 \mathrm{~mL}$ of $3 \mathrm{~N}$ $\mathrm{HCl}$ and then heated until the dilution emitted white smoke. After cooling, samples were filtered with paper Albet Ref.1300 (Filalbert, Barcelona, Spain) in a 50-mL volumetric flask, and the process was repeated in the capsule that contained the ashes to dissolve any remains. The volume was completed with ultrapure water so that a 1:5 dilution resulted for analysis. The 1:5 dilution was directly used for $\mathrm{Fe}$, but $\mathrm{Zn}$ was diluted to $1: 10, \mathrm{Na}$ and $\mathrm{Mg}$ were diluted to $1: 250$, and $\mathrm{Ca}$ and $\mathrm{K}$ were diluted to 1:500 to adjust concentrations to calibration lines.

Ash samples were examined with an atomic absorption spectrophotometer (Perkin-Elmer 2280, Boston, $\mathrm{MA})$. The concentrations of $\mathrm{Ca}, \mathrm{Mg}, \mathrm{Fe}$, and $\mathrm{Zn}$ were analyzed with atomic absorption spectrophotometry, whereas $\mathrm{K}$ and $\mathrm{Na}$ were examined using atomic emission (using the same equipment without the hollow cathode lamp used previously). In the case of $\mathrm{Ca}, 0.2 \%$ lanthanum trichloride was used to prevent interference from other elements. The spectrum lines for $\mathrm{Ca}, \mathrm{Mg}$, $\mathrm{Na}, \mathrm{K}, \mathrm{Zn}$, and $\mathrm{Fe}$ were, respectively, 422.7, 285.2, 589.0, 766.5, 213.9, and 248.3. Absorbance was measured at 2-s intervals. Each datum was the mean of 5 measures recorded at the interval mentioned, after checking that their variation coefficient was $<2 \%$. For $\mathrm{P}$ determination, UV visible spectrophotometry was used according to the colorimetric method, analyzing it as phosphomolybdic acid according to Osborne and Voogt (1978). The equipment used was a Shimadzu UV 1230 
Table 2. General linear mixed models of factors affecting milk mineral concentration during lactation in 56 Iberian red deer hinds

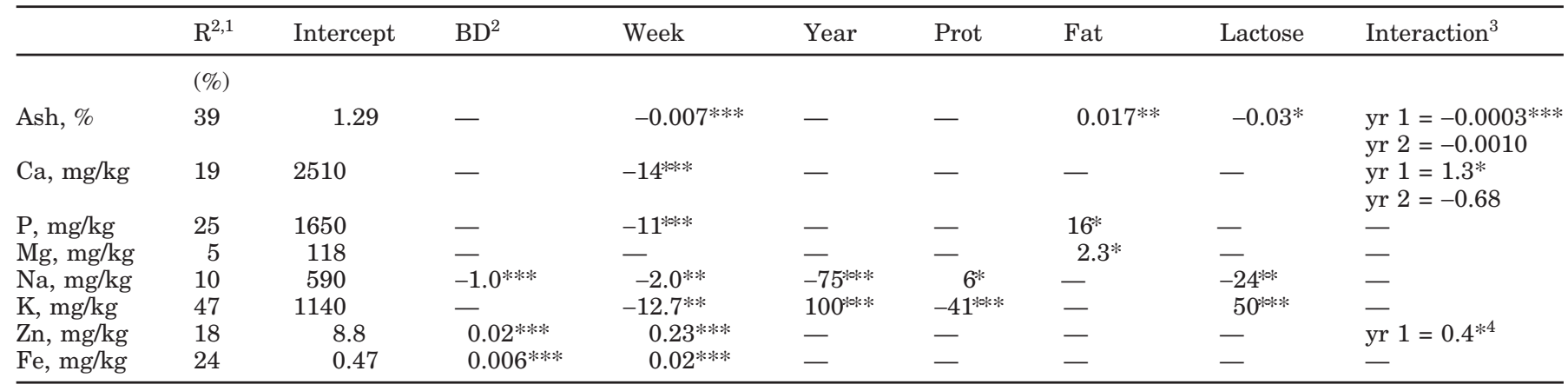

${ }^{1}$ Because general linear mixed models are calculated by restricted maximum likelihood methods, which do not provide an estimate of the variance explained by the model, $\mathrm{R}^{2}$ was calculated by a linear regression using the significant factors and interactions shown in this table for each mineral.

${ }^{2} \mathrm{BD}=$ birth date delay, which indicates the quantitative effect of delay (in days) with respect to first calf born each year (2 seasons included). Week = week (stage) of lactation. Year removes the confounding effect of differences between the 2 yr studied. Protein, fat, and lactose show, respectively, how the percentage of those nutrients in milk affected the model. Total milk yield was also included as a factor, but was not significant.

${ }^{3}$ Because the span of births was much broader in one of the $2 \mathrm{yr}$, this interaction shows the coefficients for the first year (yr 1) and second (yr 2) year of the study, respectively.

${ }^{4}$ The model did not produce a coefficient for the second year.

$* P<0.05 ; * * P<0.01 ; * * * P<0.001$.

spectrophotometer at $650-\mathrm{nm}$ wavelength (Shimadzu Co., Kyoto, Japan).

To assess the precision of the method used to determine mineral concentration, we analyzed 5 samples of skim milk powder supplied by the Community Bureau of Reference (BCR-63, Belgium, Brussels).

\section{Statistical Analyses}

A repeated measures general linear mixed models examined the effect of stage of lactation (week effect as a repeated factor; Table 2) and birth date delay in days with respect to first calf born after controlling for the confounding effects of year, protein, fat, and lactose percentage. The latter 2 effects were included because, at least in the case of protein and lactose, it is widely known that caseins interact with $\mathrm{Ca}$ and $\mathrm{Mg}$ phosphate (Vegarud et al., 2000; Silva et al., 2001), and lactose is osmotically active, and its concentration affects $\mathrm{Na}$ and $\mathrm{K}$ (Peaker, 1977). Because the span of the birth season was greater in the second year (including late calvings, as explained previously), the model also included the interaction calving date by year. Finally, Pearson correlations examined the relationship between mean concentrations per lactation of the minerals studied and between these and the main lactation variables such as total milk production; protein, fat, and lactose percentages in milk; calf birth weight; calf weight gain during lactation; hind weight at calving; and change of hind weight during lactation.

\section{RESULTS}

Mean mineral composition for red deer milk was as follows: $1.168 \pm 0.007 \%$ of fresh milk for ash, $\mathrm{Ca}=2,330$ $\pm 20 \mathrm{mg} / \mathrm{kg}, \mathrm{P}=1,640 \pm 10 \mathrm{mg} / \mathrm{kg}, \mathrm{K}=1,100 \pm 10 \mathrm{mg} /$ $\mathrm{kg}, \mathrm{Na}=385 \pm 3 \mathrm{mg} / \mathrm{kg}$, and $\mathrm{Mg}=138 \pm 1 \mathrm{mg} / \mathrm{kg}$. Concentrations of $\mathrm{Zn}$ and Fe were, respectively, $12.5 \pm$ 0.2 and $0.65 \pm 0.03 \mathrm{mg} / \mathrm{kg}$. Figures 1 and 2 show changes in milk mineral composition across the lactation of animals calving within the standard birth season, whereas Figure 3 shows protein and lactose for comparison. These figures show that mean concentrations of $\mathrm{Ca}, \mathrm{Mg}$, $\mathrm{Na}$, and $\mathrm{P}$ were remarkably stable throughout lactation, yet week had a statistically significant effect for all but $\mathrm{Mg}(P<0.01$; Table 2$)$. In contrast to such slight trends, $\mathrm{K}$ showed a decline from wk $10(P<0.01$; Table 2$)$, whereas $\mathrm{Zn}$ and $\mathrm{Fe}$ showed a concentration rising with week of lactation $(P<0.001$; Table 2$)$. In this latter case, rising concentration might help to keep mean daily transfer from mother to calf relatively stable, as Figure 4 shows. In contrast, daily production of other milk minerals decreased by about two-thirds from the beginning to the latest weeks of lactation and resembled closely the lactation curve (Figure 5).

Table 2 shows that calving date affected, either as a factor or as an interaction with year, the concentration of all minerals except $\mathrm{P}, \mathrm{Mg}$, and $\mathrm{K}$. Mean protein concentration surprisingly did not affect $\mathrm{Ca}$ or $\mathrm{P}$, but did affect $\mathrm{Na}$ and $\mathrm{K}$. As expected, lactose affected $\mathrm{Na}$ and $\mathrm{K}$ (both very active osmotically) and also ash content. More strikingly, fat percentage affected ash content as 
Table 3. Correlation between mean milk mineral concentration and lactation variables of 54 hinds calving in $2 \mathrm{yr}$ ( $1 \mathrm{yr}$ included calving delays $>60 \mathrm{~d}$ from first birth of the season). Bold typeface indicate robust correlations were consistent between a set of 13 standard lactations studied in yr 1 and the pooled data across both years

\begin{tabular}{|c|c|c|c|c|c|c|c|c|}
\hline $\begin{array}{l}\text { Milk } \\
\text { mineral }^{1}\end{array}$ & Ash & $\mathrm{Ca}$ & $\mathrm{P}$ & $\mathrm{Mg}$ & $\mathrm{Na}$ & $\mathrm{K}$ & $\mathrm{Zn}$ & $\mathrm{Fe}$ \\
\hline $\mathrm{Ca}$ & $0.91 * * *$ & & & & & & & \\
\hline $\mathrm{P}$ & $0.69 * * *$ & $0.71^{* * * *}$ & & & & & & \\
\hline $\mathrm{Mg}$ & - & - & $0.39 * *$ & & & & & \\
\hline $\mathrm{Na}$ & $-0.24^{0.08, \mathrm{a}}$ & - & - & - & & & & \\
\hline K & $0.39 * *$ & - & $0.29 *$ & - & $-0.50 * * *$ & & & \\
\hline $\mathrm{Zn}$ & $-0.30 *$ & - & - & - & - & - & & \\
\hline $\mathrm{Fe}$ & - & - & - & $0.28^{*}$ & - & $0.30 *$ & - & \\
\hline Prot & $0.36^{* *}$ & $0.23^{0.09}$ & - & - & - & - & -0.26 *** & - \\
\hline Fat & - & - & $0.27^{*}$ & $0.36 * *$ & - & - & - & $0.28 *$ \\
\hline Lact & - & - & - & $-0.46^{* * * *}$ & - & - & - & $-0.23^{0.09}$ \\
\hline TMY & - & - & - & $-0.27^{0.06}$ & - & - & - & - \\
\hline CBW & - & - & - & - & - & - & $0.30 *$ & - \\
\hline CG & - & - & - & $-0.37 * *$ & $-0.23^{0.09}$ & - & - & $-0.28^{*}$ \\
\hline HBW & - & - & - & - & $-0.30 *$ & - & $0.42 * * *$ & - \\
\hline HWC & - & - & - & $-0.48^{* * *}$ & - & - & - & $-0.24^{0.08}$ \\
\hline
\end{tabular}

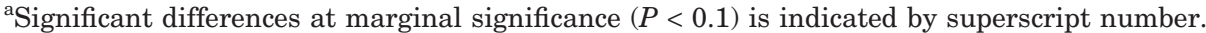

${ }^{1}$ Prot $=$ milk protein percentage, fat $=$ milk fat percentage, lact $=$ milk lactose percentage, TMY $=$ total milk yield, $\mathrm{CBW}=$ calf birth weight, $\mathrm{CG}=$ calf gains during lactation, $\mathrm{HBW}=$ hind $\mathrm{BW}$ after calving, and $\mathrm{HWC}=$ hind $\mathrm{BW}$ change from parturition to weaning.$$
* P<0.05 ; * * P<0.01 ; * * * P<0.001 \text {. }
$$

well as Mg and P. Finally, Table 3 shows the correlation among milk minerals and the correlation between these and milk protein, fat, and lactose as well as other lactation variables.

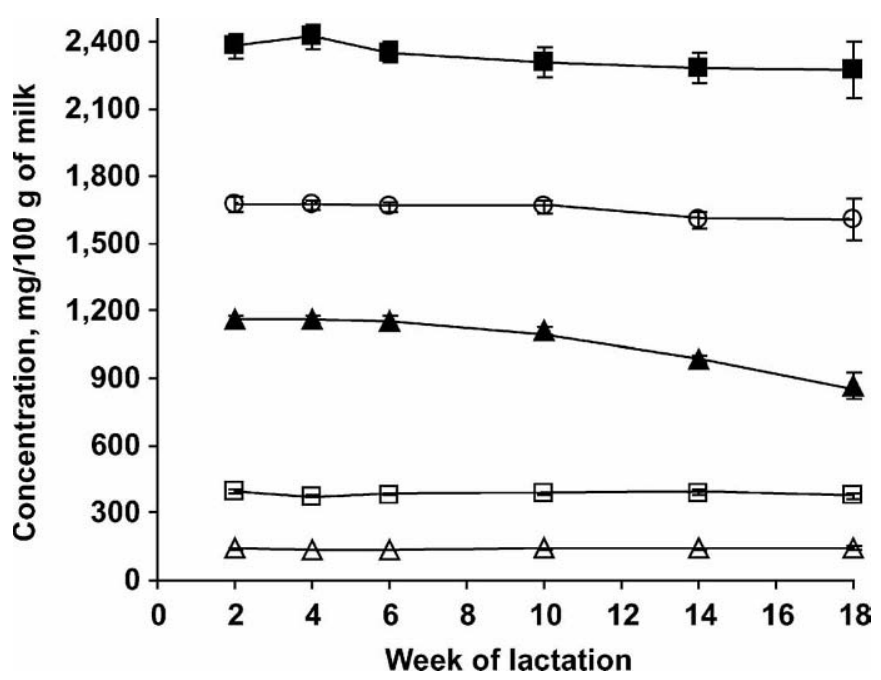

Figure 1. Concentrations of $\mathrm{Ca}(\boldsymbol{\square}), \mathrm{P}(\mathrm{O}), \mathrm{K}(\boldsymbol{\Delta}), \mathrm{Na}(\square)$, and $\mathrm{Mg}$ $(\triangle)$ during 18 wk of lactation in milk from Iberian red deer calving in the standard calving season (late-calving hinds not included). Except for a decline in $\mathrm{K}$ concentrations later in lactation, most of these minerals were maintained at relatively constant concentrations, although week of lactation had small but significant effects on $\mathrm{Ca}, \mathrm{P}$, $\mathrm{K}$, and $\mathrm{Na}$.

\section{DISCUSSION}

Factors such as week of lactation and calving date that affect milk protein, fat, lactose, and other lactation variables in Iberian red deer also affected milk mineral composition, although the effects were not the same for all minerals studied.

In the current study and in a previous report (Vergara et al., 2003), general linear mixed models showed that macromineral milk content was affected by week of

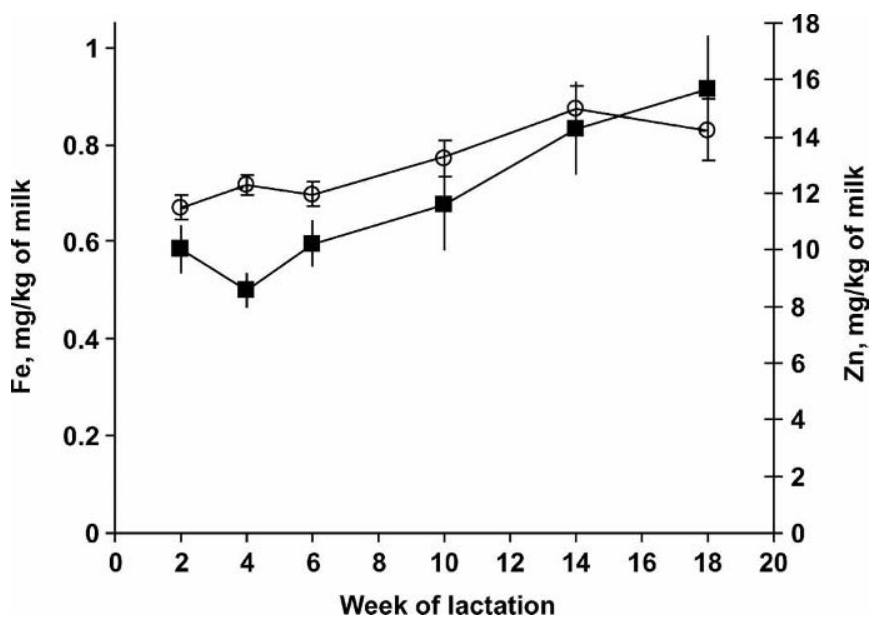

Figure 2. Concentrations of $\mathrm{Fe}(\mathbf{\square})$ and $\mathrm{Zn}(\bigcirc)$ during 18 wk of lactation in milk from Iberian red deer calving in the standard calving season (late-calving hinds not included). 


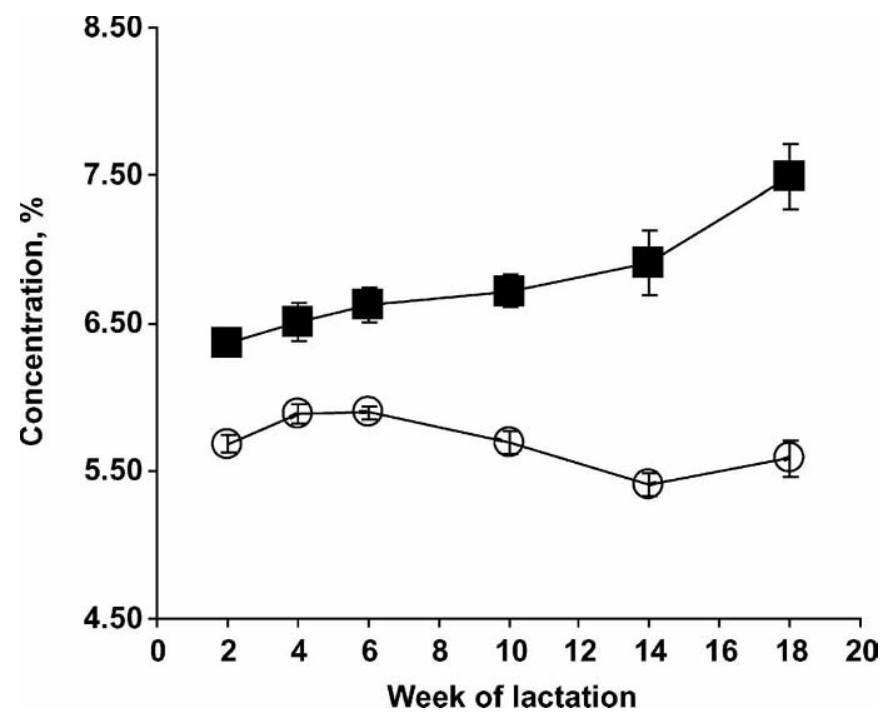

Figure 3. Concentrations of protein $(\boldsymbol{\square})$ and lactose $(\bigcirc)$ during 18 wk of lactation in milk from Iberian red deer calving within the standard calving season (late-calving hinds not included). Protein and lactose have been included rather than fat, as they are known to interact with minerals in milk, either because they form micelles (as is the case of casein) or because they are osmotically active (lactose).

lactation ( $\mathrm{Na}$ and $\mathrm{K}$ in both studies, and $\mathrm{Ca}$ and $\mathrm{P}$ in the current results). However, the effect of week was small, and concentrations of macrominerals remained relatively constant. This is illustrated by the variation in concentration of $\mathrm{Ca}$ and $\mathrm{Mg}$, which were $<7 \%$ (assessed as the deviation from unity in the ratio between the highest and the lowest concentration), or that of $\mathrm{Na}$ and $\mathrm{P}$, which were $<4 \%$. A similar stability of $\mathrm{Ca}$

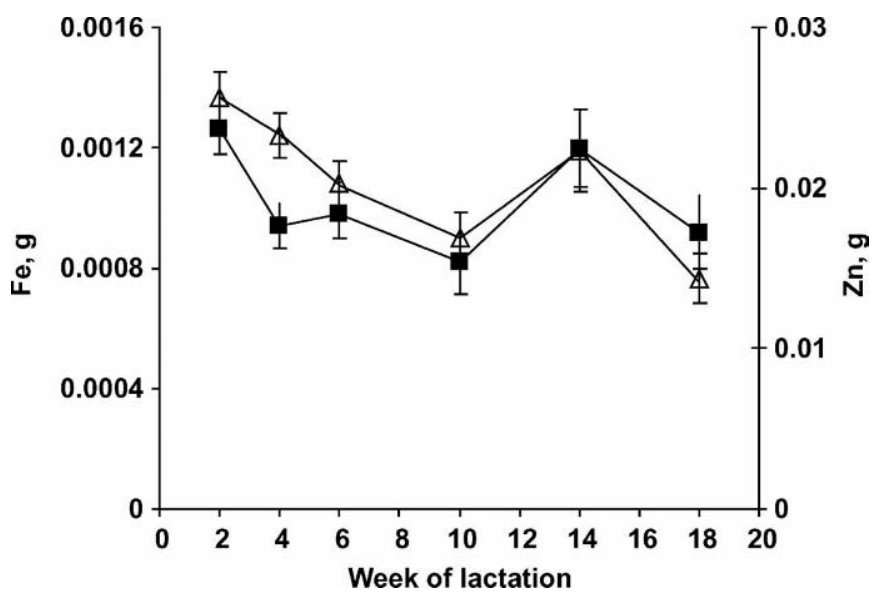

Figure 4. Daily yields of $\mathrm{Fe}(\square)$ and $\mathrm{Zn}(\triangle)$ during 18 wk of lactation in milk from Iberian red deer born within the standard season (late-calving hinds not included). Shape of curve is less steep, and decrease is more balanced, than that of other minerals because of increases in concentration of $\mathrm{Fe}$ and $\mathrm{Zn}$ as milk yield decreases.

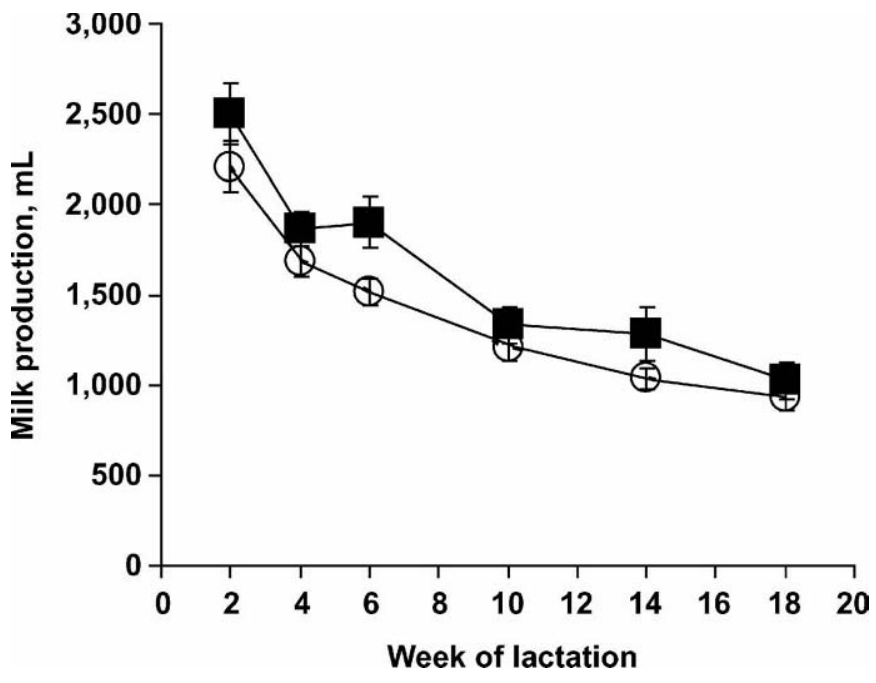

Figure 5. Daily milk yields across 18 wk of lactation for hinds calving in the standard seasonal period $(\mathbf{\square} ;<50 \mathrm{~d}$ after birth of first calf) or calving later $(O$; delay $>80 \mathrm{~d}$ after birth of first calf). Daily yields of milk $\mathrm{Ca}, \mathrm{P}, \mathrm{K}, \mathrm{Na}$, and $\mathrm{Mg}$ (data not shown) closely resemble the lactation curves shown here.

and $\mathrm{P}$ content in milk has been reported in cattle, even when the effect compared included feed restriction (Fisher et al., 1970). There is evidence that milk has evolved to carry as much $\mathrm{Ca}$ and $\mathrm{P}$ as possible (Holt, 1997); thus, Ca content of milk might be near maximum, and its concentration might be important in maintaining consistent transfer of $\mathrm{Ca}$ to calf. The $\mathrm{Ca}$ supply is very important because a reduction in transfer may greatly affect bone mechanical properties of the calf: a decrease in Ca content from $260 \mathrm{mg}$ of $\mathrm{Ca} / \mathrm{g}$ of dry bone to only $200 \mathrm{mg} / \mathrm{g}$ results in a reduction in elasticity (Young's modulus) from 25 to $5 \mathrm{GPa}$ (Currey, 2003). Thus, it is not surprising that such concentration in milk varies very little across weeks of lactation so that the transfer of calcium phosphate to the calf is only limited by the volume of milk produced. In addition, a stable concentration in milk can be easily achieved because calcium phosphate needed in mammal lactation does not depend on feed intake, as it is primarily met by bone resorption (Wysolmerski, 2002). Although not studied in such detail, this might also be the case for $\mathrm{Mg}$, which was not affected by week of lactation, as magnesium phosphate comprises $3 \%$ of bone composition (Doyle, 1979).

In contrast to the other minerals discussed, concentrations of $\mathrm{Fe}$ and $\mathrm{Zn}$ increased markedly with increasing week of lactation. This can be assessed easily both in Figures 1 and 2 as well as by the variation in concentrations mentioned previously. Thus, compared with the $7 \%$ variation just discussed, $\mathrm{Zn}$ varied by a remarkable $30 \%$ (a 4 to 7 times higher percentage variation), 
and $\mathrm{Fe}$ varied by $83 \%$ (10 and 20 times the variation of the macrominerals mentioned). Increases in concentration of $\mathrm{Fe}$ and $\mathrm{Zn}$ tend to compensate the reduction in milk production and thus keep mean daily transfer from mother to calf relatively constant. Again, both ratios and the comparison between mean daily production vs. Figure 4 suggest this is the case. While mean daily macrominerals varied by $>100 \%$ throughout lactation $(\mathrm{Ca}=135 \%, \mathrm{P}=130 \%, \mathrm{Mg}=118 \%$, and $\mathrm{Na}=126 \%)$, $\mathrm{Zn}$ varied by only $79 \%$, and Fe varied by only $55 \%$.

Why compensate $\mathrm{Fe}$ and $\mathrm{Zn}$ and not other minerals? In general, an adaptation that meets most micromineral needs of the calf such as Fe or Zn, might be easier than an adaptation to meet needs for macrominerals, for example, Ca required for skeleton growth. In addition, deficiency of $\mathrm{Fe}$ is one of the most common of those affecting all mammals (including humans), and for ruminants, deficiency is limited usually to growing animals (McDowell, 2003). In the case of $\mathrm{Zn}$, compensatory content late in lactation might be particularly important because many soils and pastures are often $\mathrm{Zn}$ deficient and because of the role of $\mathrm{Zn}$ in skeleton and general growth (McDowell, 2003). In addition, both Fe and $\mathrm{Zn}$ are the only minerals included in this study with important immunological functions, and a moderate deficiency may even result in death (Rivera et al., 2003). Collectively, those important functions might have provided a competitive advantage for calves whose dams had higher concentrations of $\mathrm{Fe}$ and $\mathrm{Zn}$ in milk as lactation advanced.

Sodium had a remarkably constant concentration in the current study, but other studies on cattle have reported $93 \%$ variation across weeks of lactation (Fisher et al., 1970). In comparisons between species, concentration of both $\mathrm{Na}$ and $\mathrm{K}$ is inversely correlated with lactose to maintain osmolality (Peaker, 1977). Similarly, both were the only minerals affected by lactose and protein, which can also exert osmotic pressure (Ahlqvist, 2004). However, $\mathrm{K}$ decreased markedly at the end of lactation, as has been observed in cattle (Fisher et al., 1970). The reason for this is not apparent, as lactose concentration is remarkably constant in deer milk even under feed restriction (Landete-Castillejos et al., 2000b; 2003a; Figure 3). Another characteristic of $\mathrm{K}$ concentration is that it is lower than that of $\mathrm{Ca}$, in contrast to what happens in cow's milk, which is consistent with findings by other researchers (Arman et al., 1974; Csapo et al., 1987; Krzywinski et al., 1980).

An effect of calving date was observed on milk mineral content, which was similar to that occuring for milk protein, fat, and lactose (Landete-Castillejos et al., 2000b, 2004, 2005). Lower growth rate of calves associated with a delay in birth date may be in part due to the observed decrease in $\mathrm{Ca}$ and $\mathrm{P}$ as well as lower milk production and other changes in milk composition from hinds that calve later (Landete-Castillejos et al., 2000b, 2001, 2005). Somewhat more surprising is the fact that $\mathrm{Na}$ decreased with increasing birth date delay, a similar trend to what occurred with lactose, although an inverse relationship should be expected (Peaker, 1977). The increase in concentration of $\mathrm{Zn}$ and Fe may result from the general increase in milk concentration that occurs as calving is delayed (Landete-Castillejos et al., 2000b) or perhaps partly to compensate for the lower milk production as it has been discussed for the effect of week of lactation.

Finally, correlations showed a mixture of strong and expected results with other more novel relationships. As expected, $\mathrm{Ca}$ and $\mathrm{P}$ were positively correlated, which was similar to relationships observed in milk from many species of mammals (Vergara et al., 2003). Calcium also had a weak, marginally significant correlation with protein content, but $\mathrm{Mg}$ was not positively correlated with either Ca or protein, in contrast to previous studies (Vergara et al., 2003). However, Mg did have a positive relationship with $\mathrm{P}$, as expected from the role of magnesium phosphate in bone construction (Doyle, 1979). As mentioned previously, Na and K were inversely related, although neither mineral was correlated with lactose as in previous studies (Vergara et al., 2003). Studies with transgenic mice show that, at least in some cases, lactose content can be dissociated with that of $\mathrm{Na}$ and $\mathrm{K}$ (Vilotte, 2002), although as mentioned before, they are usually linked (Peaker, 1977). Other relationships appear to be less clear, although some of them were very strong, such as the positive relationship between hind weight and $\mathrm{Zn}$, which might reflect a greater $\mathrm{Zn}$ store in heavier hinds; the inverse relationship between $\mathrm{Mg}$ and hind weight change during lactation; and the relationship between $\mathrm{Mg}$ and milk lactose content. Those relationships might be valuable to prompt further studies on physiology of minerals during lactation.

In conclusion, factors affecting gross milk composition, such as week of lactation and birth date delay, also affect its mineral concentration. While the effect is slight in macrominerals, a sharp increase in concentration of $\mathrm{Fe}$ and $\mathrm{Zn}$ with week of lactation appears to compensate for reduction in daily milk production.

\section{ACKNOWLEDGMENTS}

This study was supported by projects PBI-02033 (Junta de Comunidades de Castilla-La Mancha) and AGL2003-08547 (Ministerio de Ciencia y Tecnologia). The authors thank Jose Angel Gómez Nieto and Maria Jesús Lorenzo for help in data collection, Fulgencio Cebrián and Isidoro Cambronero for help in handling the 
animals, CERSYRA for help in milk analyses, and 2 anonymous referees. Statistical analyses were greatly improved by advice of Matías Gámez, UCLM, Albacete, Spain, and María del Carmen Romero, Facultad de Exactas at Tandil, Argentina.

\section{REFERENCES}

Ahlqvist, J. 2004. Equation for osmotic pressure of serum protein (fractions). J. Appl. Physiol. 96:762-764.

Arman, P., R. N. B. Kay, E. D. Goodall, and G. A. M. Sharman. 1974. The composition and yield of milk from captive red deer (Cervus elaphus L.). J. Reprod. Fertil. 37:67-84.

Brelurut, A., A. Pingard, and M. Thériez. 1990. Le Cerf et Son Élevage. INRA, Paris, France.

Csapo, J., L. Sugar, A. Horn, and Z. Csapo-Kiss. 1987. Chemical composition of milk from red deer, roe and fallow deer kept in captivity. Acta Agron. Hungarica 36:359-372.

Currey, J. D. 2003. Role of collagen and other organics in the mechanical properties of bone. Osteoporo. Int. 14:S29-S36.

Doyle, J. J. 1979. Toxic and essential elements in bone-A review. J. Anim. Sci. 49:482-497.

Fisher, L. J., A. I. Macintosh, and R. B. Carson. 1970. Effects of ad libitum versus restricted intake of concentrate and stage of lactation on the mineral content of cow's milk. Can. J. Anim. Sci. 50:121-127.

Flynn, A., and K. Cashman. 1997. Nutritional aspects of minerals in bovine and human milks. Pages 233-256 in Advanced Dairy Chemistry, Vol. 3: Lactose, Water, Salts and Vitamins, 2nd ed. P. F. Fox, ed. Chapman and Hall, London, UK.

García, A., T. Landete-Castillejos, J. Garde, and L. Gallego. 2002. Reproductive seasonality in female Iberian red deer. Theriogenology 58:1553-1562.

Holt, C. 1997. The milk salts and their interaction with casein. Pages 233-256 in Advanced Dairy Chemistry, Vol. 3: Lactose, Water, Salts and Vitamins, 2nd ed. P. F. Fox, ed. Chapman and Hall, London, UK.

Krzywinski, A., K. Krzywinska, J. Kisza, A. Roskosz, and A. Kruk. 1980. Milk composition, lactation and the artificial rearing of red deer. Acta Theriol. 25:341-347.

Landete-Castillejos, T., A. Garcia, and L. Gallego. 2001. Calf growth in captive Iberian red deer (Cervus elaphus hispanicus): Effect of birth date and hind milk production and composition. J. Anim. Sci. 79:1085-1092.

Landete-Castillejos, T., A. Garcia, J. Garde, and L. Gallego. 2000a. Milk intake and yield curves and allosuckling in captive Iberian red deer (Cervus elaphus hispanicus). Anim. Behav. 60:679-687.
Landete-Castillejos, T., A. García, J. A. Gómez, and L. Gallego. 2003a. Lactation under food constraints in Iberian red deer (Cervus elaphus hispanicus). Wildl. Biol. 9:131-139.

Landete-Castillejos, T., A. García, J. A. Gómez, M. I. Berruga, and L. Gallego. 2004. Lactation under induced five-month delay reproduction in Iberian red deer (Cervus elaphus hispanicus). J. Exp. Zool. 301A:261-265.

Landete-Castillejos, T., A. García, J. A. Gomez, M. I. Berruga, and L. Gallego. 2005. Effects of birth date and order in lactation performance of Iberian red deer (Cervus elaphus hispanicus). J. Dairy Sci. 88:154-158.

Landete-Castillejos, T., A. García, J. A. Gómez, and L. Gallego. 2003b. Subspecies and body size effect on lactation biology in red deer: Comparison of Cervus elaphus hispanicus and C. e. scoticus. Physiol. Biochem. Zool. 76:594-602.

Landete-Castillejos, T., A. García, P. Molina, H. Vergara, J. Garde, and L. Gallego. 2000b. Milk production and composition in captive Iberian red deer (Cervus elaphus hispanicus): Effect of birth date. J. Anim. Sci. 78:2771-2777.

McDowell, L. R. 2003. Minerals in Animal and Human Nutrition. Elsevier, Amsterdam, The Netherlands.

Osborne, D. R., and P. Voogt. 1978. The Analysis of Nutrients in Foods. Acad. Press, London, UK.

Paik, I. 2001. Application of chelated minerals in animal production. Asian-Australian J. Anim. Sci. 14:191-198.

Peaker, M. 1977. The aqueous phase of milk: Ion and water transport. Symp. Zool. Soc. Lond. 41:113-134.

Rivera, M. T., A. Pereira De Souza, T. Cremonini Araujo-Jorge, S. Lisboa De Castro, and J. Vanderpas. 2003. Trace elements, innate immune response, and parasites. Clin. Chem. Lab. Med. 41:1020-1025.

Silva, F. V., G. S. Lopes, J. A. Nóbrega, G. B. Souza, and A. R. A. Nogueira. 2001. Study of the protein-bound fraction of calcium, iron, magnesium, and zinc in bovine milk. Spectrochimica Acta B 56:1909-1916.

Vegarud, G. E., T. Langsrud, and C. Svenning. 2000. Mineral-binding milk proteins and peptides; occurrence, biochemical, and technological characteristics. Br. J. Nutr. 84:S91-S98.

Vergara, H., T. Landete-Castillejos, A. García, P. Molina, and L. Gallego. 2003. Concentration of $\mathrm{Ca}, \mathrm{Mg}, \mathrm{K}, \mathrm{Na}, \mathrm{P}$, and $\mathrm{Zn}$ in milk in two subspecies of red deer: Cervus elaphus hispanicus and $C$. e. scoticus. Small Rumin. Res. 47:77-86.

Vilotte, J. L. 2002. Lowering the milk lactose content in vivo: Potential interests, strategies, and physiological consequences. Reprod. Nutr. Dev. 42:127-132.

Wysolmerski, J. J. 2002. The evolutionary origins of maternal calcium and bone metabolism during lactation. J. Mammary Gland Biol. Neoplasia 7:267-276. 